на долю которого приходилось столько труда, не падало, а росло и крепло, и в 1676 г. оно было совсем иным, чем в 1645 г.: оно стало гораздо крепче как в отношении политического строя, так и в отношении благосостояния» $[8$, с. 428$]$.

$$
* * *
$$

1. Берх В. Н. Царствование Алексея Михайловича. - М. : Кучково поле, 2013. - 352 с.

2. Ключевский В. О. Русская история. Полный курс лекций в 2-х кн. Кн. 2. - М. : ОЛМА-ПРЕСС, 2003. $-800 \mathrm{c}$.

3. Ключевский В. О. Русская история. Полный курс лекций в 2-х кн. Кн. 2. - М. : ОЛМА-ПРЕСС, 2003. $-800 \mathrm{c}$.

4. Уланов В. Финансовые реформы царя Алексея Михайловича и «гиль» 1662 г. Три века. Том первый : сб. / сост. А. М. Мартышкин, А. Г. Свиридов. - М. : Патриот, 1991. - 286 с.

5. Вернадский Г. Московское царство. - М. : Ломоносовъ, 2017. -456 с.

6. Уланов В. Финансовые реформы царя Алексея Михайловича и «гиль» 1662 г. Три века. Том первый : сб. / сост. А. М. Мартышкин, А. Г. Свиридов. - М. : Патриот, 1991. - 286 с.

7. Костомаров Н. И. Раскол. Исторические монографии и исследования. Серия : Актуальная история России. - М. : «Чарли», 1994. - 608 с.

8. Платонов С. М. Полный курс лекций по русской истории. - М. : АСТ МОСКВА, 2008. - 861 с.

Куваева Л.В., Засеева А.В.

\title{
Анализ численности населения Северного Кавказа во второй половине XX века
}

Северо-Кавказский социальный институт

(Россия, Ставрополь)

doi:10.18411/spc-01-04-2018-09

idsp: 000001:spc-01-04-2018-09

С 1959 г. численность городского населения Северного Кавказа стала расти быстрее, чем в целом по Российской Федерации. Повсеместный рост числа городских жителей сопровождался ростом числа городских поселений. На Северном Кавказе темпы роста числа городских поселений в 1959-1988 гг. были выше, чем в среднем по Российской Федерации. Особенно быстро росло число городов, которые возникали чаще всего путем преобразования крупных сельских поселений в городские.

К 1959 г. Северный Кавказ концентрировал 11,9\% сельского населения России, а к 1989 г. - уже 18,3\%. Таким образом, налицо все большая концентрация сельского населения России на Северном Кавказе [2].

Численность сельского населения в Российской Федерации сокращалась на протяжении всего периода 1926-1988 гг. На Северном Кавказе сокращение численности сельского населения наблюдалось не всегда. Так, в 1959-1969 и 1979-1988 гг. наблюдалось увеличение численности сельского населения. Да и в другие периоды темпы сокращения были значительно ниже, чем в целом по Российской Федерации.

Потеряв всякую надежду на государство и работу от него, население из других регионов России (Европейского Севера, Сибири и Дальнего Востока) прибывало на «теплый» и «сытый» Северный Кавказ в надежде прокормиться от земли.

За 1959-1988 гг. внутри Северного Кавказа численность населения увеличилась в Чечено-Ингушетии в 1,8 раза, Дагестане в 1,4 раза, Кабардино-Балкарии в 1,2 раза и оставалась практически неизменной (при некотором увеличении) в Ставропольском и Краснодарском краях. В других регионах наблюдалось сокращение численности сельского населения.

В 1989-1997 гг. сельское расселение Северного Кавказа испытало значительный приток населения из других регионов России и стран СНГ. Темпы прироста сельского населения Северного Кавказа были самыми высокими, начиная с 1926 г. Заметим, что в целом и в Российской Федерации, впервые с 1926 г. сельское население стало расти [1]. 
За 1989-1997 гг. почти во всех регионах Северного Кавказа (за исключением Чечни) наблюдалось увеличение численности сельского населения. Наибольшее увеличение численности наблюдалось в Кабардино-Балкарии, Ростовской области, Карачаево-Черкесии, Краснодарском и Ставропольском краях. Не имея возможности судить о динамике численности населения за 1989-1993 гг., мы можем констатировать, что за 1994-1996 гг. сельское население республики увеличилось на 14,6\%. В других регионах численность сельского населения увеличилась незначительно. В Чеченской Республике численность сельского населения сократилась на 9,2\% [4].

Территориальная дифференциация численности сельского населения на Северном Кавказе привела к изменению удельного веса его регионов. Доля Ростовской области, Краснодарского и Ставропольского краев в сумме за 1959-1997 гг. снизилась с $68,8 \%$ до 63,1\%. Особенно значительно снизился удельный вес Ростовской области (с 21,3 до 18,0\%). Доля Краснодарского края снизилась с 31,2 до 29,5\%, а доля Ставропольского края - с 16,3 до 15,5\%. Снизился удельный вес Северной Осетии, Адыгеи и Карачаево-Черкесии. В то же время повысился удельный вес Чечни и Ингушетии, Дагестана и Кабардино-Балкарии.

Таким образом, к 1997 г. республики, края и области Северного Кавказа подошли с разными результатами, с различной расселенческо-демографической обстановкой [3].

Проведенное исследование динамики численности населения Северного Кавказа в целом, и Северной Осетии в частности, позволяет сделать следующие выводы:

1. К концу XX века на Северном Кавказе, в том числе Северной Осетии в частности, впервые в мирное время стала наблюдаться естественная убыль населения. Отметим, что этот сложный и негативный процесс набирает обороты на всей территории Российской Федерации.

2. В настоящее время на Северном Кавказе только в Дагестане и Ингушетии обеспечивается простое воспроизводство населения. В других республиках и административно-территориальных образованиях Северного Кавказа наблюдается либо естественная убыль населения, либо суженное воспроизводство населения.

3. В целом по России естественная убыль населения в 90-х гг. ХХ в. наблюдалась на 3 года раньше, чем на Северном Кавказе, включая и Северную Осетию.

4. Наблюдаются значительные различия в уровне демографической освоенности территории. Северная Осетия относится к регионам с высоким уровнем освоенности индустриально-аграрного типа.

$$
* * *
$$

1. Тавасиев В.Х. Заселение территории Северной Осетии и численность ее населения в начале XX века// Вестник университета (Государственный университет управления), №9 (47). - Москва, 2008. C.143-146.

2. Тавасиев В.Х. Историко-демографический анализ национального состава и численности населения Северной Осетии в XX веке: Дис. ....канд. истор. наук. - Владикавказ, 2006. - 186 с.

3. Тавасиев В.X. Социально-демографическое развитие Северной Осетии в XX веке. - Владикавказ: Изд-во «Олимп», 2013.

4. Тавасиев В.Х., Ревазов В.Ч. Население Северной Осетии в XX веке. - Владикавказ: Изд-во «Олимп», 2014. - 173 с. 